\title{
The Impact of Motivation and Environment on Employee Performance with Organizational Commitment as Intervening Variable
}

\author{
Adelfigita Frastika1, Rosaly Franksiska ${ }^{2 *}$
}

${ }^{1,2}$ Satya Wacana Christian University, Salatiga, Indonesia

\section{ART ICLE INFO}

\section{Article history:}

Received September 01, 2021

Revised September 03, 2021

Accepted October 22, 2021

Available online November 25, 2021

Keywords:

Work Motivation, Work Environment, Employee Performance

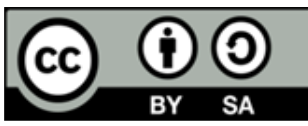

This is an open access article under the CC BY-SA license.

Copyright (c) 2021 by Author. Published by Universitas Pendidikan Ganesha.

\begin{abstract}
A B S T R A C T
Employee performance is the result achieved by the employee in completing the work assigned by the company to the employee. The inconsistencies of previous research and also overlooking the chance that organizational commitment may act as intervening variable is the problem that this research highlight. The purpose of the study was to test the effect of work motivation and work environment on employee performance with organizational commitment as an intervening variable. This type of research is causal-quantitative research. Saturation sampling was used in this research. 110 employees of PT Abioso Batara Alba, Boyolali Regency, as the sample. Data collection techniques in this study using a questionnaire. The hypothesis testing technique is in the form of path analysis using SPSS version 20 and the Sobel test. The results showed that work motivation had an effect on employee performance. Organizational commitment does not mediate the effect of work motivation on employee performance. Good work motivation will increase employee performance. The work environment has an effect on employee performance. Organizational commitment does not mediate the effect of the work environment on employee performance. Employee performance will improve if they are motivated at work. Employees do not need to be devoted to the firm to increase performance because the company's good work motivation will directly improve employee performance. Employees do not need to be dedicated to the company first in order for the construction of a nice work environment to have a direct impact on employee performance.
\end{abstract}

\section{INTRODUCTION}

Employee performance will not be optimal if they only rely on production machines without paying attention to the human aspect. Employee performance is the result achieved by employees in completing the work assigned by the company to the employee (Hasibuan, 2012; Sari et al., 2021). It must be remembered that in a corporate organization, the human aspect of being capable, skilled, and responsible as an employee is a company asset that is very valuable for the survival of the company (Govender \& Bussin, 2020; Veithzal, 2005). One of the factors that affect employee performance is work motivation. (Antonio, 2016; Neher \& Maley, 2020) reveals that work motivation is an encouragement given by an organization or company to increase employee morale. High motivation, employees will improve employee performance, employees will be more active in completing every task they do, because employees will feel more cared for, given encouragement to move forward, and feel supported by the organization.

Another factor that affects employee performance is the work environment. Work environment defined as physical and non-physical factors that affect employee work (Liang et al., 2015; Noah \& Steve, 2012; Taiwo, 2010). The physical work environment used in this study. The condition of the physical environment, especially during Covid 19, was different from conditions before Covid 19. Before Covid 19 the company did not limit the relationship between employees in the workplace. In addition, during the Covid 19 pandemic at PT Abioso Batara Alba, Boyolali Regency, they placed hand washing facilities with running water provided before workplace, as well as providing hygiene sanitation tools such as hand sanitizers at each entrance area and around the building area and more routinely cleaning the air circulation in the workspace. This is in line with statment that there are several things regarding the condition of the physical environment where employees work during Covid-19, namely air circulation, workspace size, and 
work equipment (Hustia, 2020). The better the work environment such as good relations between leaders and subordinates as well as good relations between fellow subordinates and workplace conditions will be able to improve employee performance.

In addition to work motivation and work environment, another factor that can affect employee performance is organizational commitment. Organizational commitment defined as a person's belief in the organization or company and the involvement of individuals in the activities or interests of the organization with full responsibility and loyalty to the organization (Dewi \& Amilin, 2015). The higher the organizational commitment to employees such as employees who are always involved in the organization will be able to improve employee performance. A good working environment will be able to increase a person's commitment to the organization, because with a good working environment, employees will feel comfortable and will continue to work in that place. Several previous studies found a positive influence of the work environment on organizational commitment (Abidin et al., 2017; Putra et al., 2020; Wowor, 2016). However, the results of this study differ from another studies who found that the work environment did not have a positive effect on organizational commitment (Azizah et al., 2019; I. Purnama. et al., 2019; Setiawan \& Lestari, 2016). On the other hand, other studies such as research found a positive influence of work motivation on organizational commitment (Bintoro et al., 2019; Lestari, 2016; N. Q. Purnama et al., 2016). This means that the more motivated employees will increase the employee's commitment to the organization. However, unlike the research which found work motivation did not have a positive effect on organizational commitment (D. M. Akbar et al., 2017; Azizah et al., 2019).

Previous studies found a positive influence on work motivation on employee performance (Amalia \& Fakhri, 2016; Oktavianti, 2020; Rahsel, 2016). However, the results of this study are different from another studies which found work motivation had no effect on employee performance (Muhamad \& Trang, 2019; Oktavianti, 2020; Syawal, 2018). The research supports this by finding the influence of the work environment on employee performance (Josephine \& Harjanti, 2017; Kusumastuti et al., 2019; Lestary \& Harmon, 2018). However, it is different from the findings who found the work environment had no effect on employee performance (Siahaan \& Bahri, 2019; Wasiati, 2016). Previous researchers also found a positive effect of organizational commitment on employee performance (D. M. Akbar et al., 2017; Charli et al., 2020; Lessar et al., 2019). However, this is different from the research which found organizational commitment did not have a positive effect on employee performance (Syardiansah et al., 2020). This study is a modification of previous research, this is because previous research only examined directly between the $\mathrm{X}$ variable (work motivation and work environment) on Y (employee performance), but this study examined the indirect effect by adding an intervening variable (organizational commitment). The difference of this research from previous research is in the organizational commitment variable which is studied as an intervening variable. This research was conducted because of the inconsistency of previous studies and because in previous studies organizational commitment had not been considered as an indirect variable. This study aims to test the effect of work motivation and work environment on employee performance with organizational commitment as an intervening variable.

\section{METHODS}

This type of research is descriptive quantitative by using explanation (Explanatory Research). The population of this research is the employees of PT ABA, Boyolali Regency, amounting to 110 people. The sampling technique used saturation sampling. Saturation Sampling method is a sampling method by including all members of the population as research samples (Sugiyono, 2012), so the number of samples in this study is 110 employees. The concept definition, dimension, and indicators of each variable is presented in Table 1. Data collection techniques in this study using a questionnaire. Questionnaires were distributed to employees during breaks and when they came home from work. The scale used in this study is the Likert scale. In this study the variables were measured by six categories of degrees of agreement, namely 1 = Strongly Disagree, 2 = Disagree, 3 = Slightly Disagree, $4=$ Slightly Agree, $5=$ Agree, $6=$ Strongly Agree. Hypothesis testing technique in the form of path analysis using SPSS version 20 and Sobel test.

Table 1. Variable Operations

\begin{tabular}{|c|c|c|}
\hline Concept Definition & Dimension & Indicator \\
\hline $\begin{array}{l}\text { It is the result of an employee's } \\
\text { work which is assessed based } \\
\text { on the quality and quantity of } \\
\text { work achieved in accordance }\end{array}$ & $\begin{array}{l}\text { 1. Work quality } \\
\text { 2. Working } \\
\text { quantity } \\
\text { 3. Responsibility } \\
\text { 4. Cooperation }\end{array}$ & $\begin{array}{l}\text { 1.a. According to company standards, } \\
\text { 1.b. Able to complete work on time. } \\
\text { 2.a. Work results according to target } \\
\text { 2.b. Do not procrastinate work. } \\
\text { 3.a. The ability of employees to carry out work } \\
\quad \text { according to procedures }\end{array}$ \\
\hline
\end{tabular}




\begin{tabular}{|c|c|c|}
\hline Concept Definition & Dimension & Indicator \\
\hline $\begin{array}{l}\text { with the responsibilities given } \\
\text { to the employee } \\
\text { (Mangkunegara, 2009) }\end{array}$ & 5. Initiative & $\begin{array}{l}\text { 3.b. The ability of employees to take risks. } \\
\text { 4.a. The ability of employees to cooperate with } \\
\text { other employees, }\end{array}$ \\
\hline
\end{tabular}

5.a. Employees are able to provide ideas or ideas

5.b. The ability of employees to utilize organizational resources.

Organizational Commitment
It is a strong desire as a
member of the organization to
strive in accordance with the
goals of the organization
(Luthans, 2006)
(Luthans, 2006)

\section{Affective Commitment}

1. Continuance Commitment

2. Normative Commitment

1.a. Keep working at the company because of the emotional bond

1.b. Always involved in the organization

2.a. Stay with the organization because of the appropriate salary

2.b. Keep working at the company because there is no better alternative to work elsewhere

3.a. Stay in the organization because of selfawareness

3.b. Staying in the company because there are obligations that must be done

\section{Work environment}

It is everything that is in the employee's workplace (Noah \& Steve, 2012).
Physical dimension

1. workspace lighting,

2. workspace circulation,

3. noise level,

4. room wall color,

5. Workroom air humidity

6. Existing facilities in the workspace (AC, trash cans, drinking water, toilets, prayer rooms, etc.)

Work motivation
It is a force, both internal and
external, that encourages a
person to achieve certain
predetermined goals (Uno,
2010)

1. Internal motivation

2. External motivation 1.a. Employee responsibilities for the tasks performed,

1.b. Complete tasks according to targets,

1.c. There is feedback on the work that has been completed,

1.d. Feeling happy in doing work,

1.e. Prioritizing work performance over what is done

2.a. Trying to make ends meet

2.b. Feel happy if given a compliment from the work

2.c. Work well because of the desire to get incentives and

2.d. Work because you want to get attention from superiors and coworkers

\section{RESULTS AND DISCUSSIONS}

\section{Results}

Characteristic of Respondents

This section describes the characteristics of the respondents as many as 110 employees of PT. PT ABA Boyolali Regency which consists of gender, age, last education, length of work and status.

Table 2. Characteristic of Respondents

\begin{tabular}{lccc}
\hline & Characteristic Respondent & Amount & (\%) \\
\hline Gender & Man & 49 & $44,55 \%$ \\
& Woman & 61 & $63,00 \%$ \\
& Amount & 110 & $100,00 \%$ \\
\hline
\end{tabular}




\begin{tabular}{llcc}
\hline & Characteristic Respondent & Amount & (\%) \\
\hline Age & Under 20 years & 4 & $3,64 \%$ \\
& Age 20 tahun-30 years & 52 & $47,27 \%$ \\
& Age 31 tahun-40 years & 41 & $37,27 \%$ \\
& Over 40 years old & 13 & $11,82 \%$ \\
Last Education & Amount & 110 & $100,00 \%$ \\
& Senior Haight School & 95 & $86,36 \%$ \\
& Diploma & 2 & $1,82 \%$ \\
Length of Work & Bachelor & 13 & $11,82 \%$ \\
& Amount & 110 & $100,00 \%$ \\
& 1 year - 2 years & 21 & $19,09 \%$ \\
Status & 3 years - 4 years & 65 & $59,09 \%$ \\
& > 4 years & 24 & $21,82 \%$ \\
& Amount & 110 & $100,00 \%$ \\
& Marry & 72 & $65,45 \%$ \\
& Not married yet & 38 & $34,55 \%$ \\
& Amount & 110 & $100,00 \%$ \\
\hline
\end{tabular}

Table 2 shows that most of the respondents in this study were women, amounting to $63 \%$. When viewed from the age, most of the respondents (47.27\%) aged 20-30 years. Most of the respondents' last education was high school, which was $86.36 \%$. When viewed from the length of work, most of the respondents (59.09\%) have worked for 3 years to 4 years. When viewed from the status of most of them are married by $65.45 \%$. Here are the results of the test path by using simple regression for each hypothesis by using SPSS V.23 by testing analysis test path that aims to determine the influence of an independent variable on the dependent variable. In this test using a test with a significance level of 0.05 . For more details can be seen in the following Table 3 .

Table 3. Hypothesis Testing

\begin{tabular}{|c|c|c|c|c|c|}
\hline \multicolumn{3}{|c|}{ Variable } & \multirow{2}{*}{ Sig. } & \multirow{2}{*}{$\mathbf{R}^{2}$} & \multirow{2}{*}{ Conclusion } \\
\hline $\mathbf{X}$ & $\mathbf{Z}$ & $\mathbf{Y}$ & & & \\
\hline Work Motivation & & $\begin{array}{c}\text { Employee } \\
\text { Performance }\end{array}$ & 0.000 & 0.382 & Accepted \\
\hline \multirow[t]{2}{*}{ Work Environment } & & $\begin{array}{c}\text { Employee } \\
\text { Performance }\end{array}$ & 0.000 & 0.371 & Accepted \\
\hline & $\begin{array}{l}\text { Organization } \\
\text { Commitment }\end{array}$ & $\begin{array}{c}\text { Employee } \\
\text { Performance }\end{array}$ & 0.000 & 0.391 & Accepted \\
\hline Work Motivation & $\begin{array}{l}\text { Organization } \\
\text { Commitment }\end{array}$ & & 0.000 & 0.354 & Accepted \\
\hline Work Environment & $\begin{array}{l}\text { Organization } \\
\text { Commitment }\end{array}$ & & 0.000 & 0.475 & Accepted \\
\hline
\end{tabular}

Table 3 shows that work motivation affects employee performance with a significance value 0.000 which is smaller than 0,05 . The value of $R$ Square is 0.382 , so the variation in employee performance that is influenced by work motivation is $38.20 \%$ and the rest is influenced by other variables outside the research model. The work environment variable has an effect on employee performance with a significance value of 0.000 which is smaller than 0.05 . The value of $R$ Square is 0.371 , so the variation in employee performance that is influenced by the work environment is $37.10 \%$ and the rest is influenced by other variables outside the research model. Organizational commitment variable has an effect on employee performance with a significance value of 0.000 which is smaller than 0.05 . The value of $R$ Square is 0.391 , so the variation in employee performance that is influenced by organizational commitment is $39.10 \%$ and the rest is influenced by other variables outside the research model.

The work motivation variable has an effect on organizational commitment with a significance value of 0.000 which is smaller than 0.05 . The value of $R$ Square is 0.354 , so the variation of organizational commitment that is influenced by work motivation is $35.40 \%$ and the rest is influenced by other variables outside the research model. The work environment variable has an effect on organizational commitment with a significance value of 0.000 which is smaller than 0.05 . The value of $R$ Square is 0.475 , so the variation of organizational commitment that is influenced by the work environment is $47.50 \%$ and the rest is influenced by other variables outside the research model. The results of the influence of work motivation 
on employee performance with organizational commitment as an intervening variable using the Sobel test as shown in Table 4.

Table 4. The Effect Work Motivation on Employee Performance with Organizational Commitment as an Intervening Variable

\begin{tabular}{|c|c|c|c|c|c|}
\hline Variable & & & $\begin{array}{c}\text { Standard } \\
\text { Error }\end{array}$ & $\begin{array}{l}\text { Influence } \\
\text { Direct (B) }\end{array}$ & Indirect Influence \\
\hline $\mathbf{X}$ & $\mathbf{Z}$ & $\mathbf{Y}$ & & & \\
\hline Work & & Employee & & 0,462 & \\
\hline Motivation & & Performance & & & \\
\hline \multirow{3}{*}{$\begin{array}{c}\text { Work } \\
\text { Motivation }\end{array}$} & Organizational & & 0,047 & 0,387 & \\
\hline & Commitment & & & & \\
\hline & $\begin{array}{c}\text { Organizational } \\
\text { Commitment }\end{array}$ & $\begin{array}{c}\text { Employee } \\
\text { Performance }\end{array}$ & 0,052 & 0,472 & \\
\hline Work & Organizational & Employee & & & $\left(0,387^{*} 0,472\right)=$ \\
\hline Motivation & Commitment & Performance & & & 0,183 \\
\hline
\end{tabular}

Based on Table 4, it shows that path analysis shows that the results obtained are the direct effect of work motivation on employee performance of 0.462 while the indirect effect of work motivation on employee performance through organizational commitment is 0.183 . With the multiplication result, it is obtained that the value is $0.462>0.1183$. Which means that the direct effect of work motivation on employee performance is greater than the indirect effect of work motivation on employee performance through organizational commitment. So, it can be concluded that work motivation does not mediate the effect of work motivation on employee performance. The processed results regarding the effect of the work environment on employee performance with organizational commitment as an intervening variable can be calculated as in Table 5.

Table 5. The Effect Work Environment on Employee Performance with Organizational Commitment as an Intervening Variable

\begin{tabular}{|c|c|c|c|c|c|}
\hline Variable & & & $\begin{array}{c}\text { Standard } \\
\text { Error }\end{array}$ & $\begin{array}{l}\text { Influence } \\
\text { Direct }(B)\end{array}$ & Indirect Influence \\
\hline $\mathbf{X}$ & $\mathbf{Z}$ & $\mathbf{Y}$ & & & \\
\hline Work & & Employee & & 0,452 & \\
\hline Environment & & Performance & & & \\
\hline $\begin{array}{c}\text { Work } \\
\text { Environment }\end{array}$ & $\begin{array}{c}\text { Organizational } \\
\text { Commitment }\end{array}$ & & 0,028 & 0,351 & \\
\hline & $\begin{array}{l}\text { Organizational } \\
\text { Commitment }\end{array}$ & $\begin{array}{c}\text { Employee } \\
\text { Performance }\end{array}$ & 0,052 & 0,472 & \\
\hline Work & Organizational & Employee & & & $(0,351 * 0,472)=$ \\
\hline Environment & Commitment & Performance & & & 0,166 \\
\hline
\end{tabular}

Based on the Table 5, it shows that the path analysis shows that the results obtained are the direct effect of the work environment on employee performance of 0.452 while the indirect effect of the work environment on employee performance through organizational commitment is 0.166 . With the multiplication result, it is obtained that the value is $0.452>0.166$. Which means that the direct influence of the work environment on employee performance is greater than the indirect effect of the work environment on employee performance through organizational commitment. So, it can be concluded that the work environment does not mediate the effect of the work environment on employee performance.

\section{Discussion}

Work motivation has a positive effect on employee performance

Work motivation affects employee performance with a significance value of 0.000 which is smaller than 0.05 , so $\mathrm{H} 1$ is accepted and $\mathrm{H} 0$ is rejected. This result is supported by descriptive statistics of work motivation which is included in the high category. This is because of the nine indicators of work motivation, eight are in the high category and one indicator is in the low category. The results of this study are in line with research which found a positive influence of work motivation on employee performance (Amalia \& Fakhri, 2016; Oktavianti, 2020; Rahsel, 2016). This means that the more motivated employees can improve employee performance. Work motivation is one of the important things in implementing employee 
performance in the workplace. For employees, work motivation is very important in achieving good performance or it can be said if work motivation will be related to the achievement of employee performance.

Work motivation is one of the factors that affect employee performance. Work motivation is an encouragement given by an organization or company to increase employee morale (Antonio, 2016). High motivation, employees will improve employee performance, employees will be more active in completing every task they do, because employees will feel more cared for, given encouragement to move forward, and feel supported by the organization. Work motivation is one of the important things in implementing employee performance in the workplace. For employees, work motivation is very important in achieving good performance or it can be said if work motivation will be related to the achievement of employee performance (Amalia \& Fakhri, 2016; Oktavianti, 2020; Rahsel, 2016). This means that the more motivated employees can improve employee performance.

\section{Work motivation has a positive effect on employee performance through organizational commitment}

Based on path analysis, it shows that the results obtained are a direct influence, namely work motivation on employee performance of 0.462 . Meanwhile, the indirect effect of work motivation on employee performance through organizational commitment is 0.183 . Which means that organizational commitment does not mediate the effect of work motivation on employee performance, so $\mathrm{H} 2$ is rejected and $\mathrm{HO}$ is accepted. The results of this study are in line with previous study, which suggests that organizational commitment does not mediate the effect of work motivation on employee performance (Shanty \& Mayangsari, 2017). This means that the motivation given is still not able to increase the organizational commitment of employees. This is because employees feel they have to stay with the company because they still need the company, this is because there are other factors that are considered capable of influencing employee organizational commitment to the company.

Work motivation arises because of the need and motivation encourages the emergence of action in order to meet these needs. If employees have high work motivation, the commitment in carrying out their work will increase. With this, the quality of employees can be seen from the form of attention and concern for the school. This is supported by several studies finding a positive influence on work motivation on organizational commitment (Bintoro et al., 2019; Lestari, 2016; N. Q. Purnama et al., 2016). This means that the more motivated employees will increase the employee's commitment to the organization. Organizational commitment is the involvement of people with the organization where they work and are interested in staying in the organization in an effort to improve performance. In this case, good organizational commitment will be able to improve employee performance to achieve organizational goals. This is supported by the research which found a positive influence of organizational commitment on employee performance (D. M. Akbar et al., 2017; Charli et al., 2020; Lessar et al., 2019). The same thing was also expressed by previous study, who found work motivation had an effect on employee performance mediated by organizational commitment (Shanty \& Mayangsari, 2017). The higher the organizational commitment to employees as employees is always involved in the organization will be able to improve employee performance. A good work environment will be able to increase a person's commitment to the organization, because with a good work environment employee will feel comfortable and will continue to work in that place.

\section{The work environment has a positive effect on employee performance}

The work environment affects employee performance with a significance value of 0.000 which is smaller than 0.05 , so $\mathrm{H} 3$ is accepted and $\mathrm{H} 0$ is rejected. These results are supported by descriptive statistics, namely the work environment is included in the high category, this is because there are two indicators that are included in the high category, such as the lighting in the workspace which according to employees is adequate and the air circulation in the workspace is good. The results are in line with the research that support this by finding the influence of the work environment on employee performance (Josephine \& Harjanti, 2017; Kusumastuti et al., 2019; Lestary \& Harmon, 2018). The work environment in a company is important to note. The work environment can be seen from the physical (sufficient lighting, good air temperature, noise, coloring, sufficient space for movement, security). A good work environment can support the implementation of work so that employees become more enthusiastic at work and can improve employee performance. The better the work environment such as good relations between leaders and subordinates as well as good relations between fellow subordinates and workplace conditions will be able to improve employee performance. A good work environment is a work environment that provides comfort to its employees so that when employees do work it will be able to affect their performance. A good and pleasant work environment can increase the passion and morale of the employees of PT Abioso Batara Alba, 
Boyolali Regency. A good work environment can increase the level of concentration of employees because this condition causes the level of productivity produced by employees to also increase. A good physical work environment can provide support for improving employee work performance.

The work environment is a factor that can affect employee performance. Work environment defined as physical and non-physical factors that affect employee work (Taiwo, 2010). The physical work environment used in this study. The condition of the physical environment, especially during Covid 19, was different from conditions before Covid 19. Before Covid 19 the company did not limit the relationship between employees in the workplace. In addition, during the Covid 19 pandemic at PT ABA, Boyolali Regency, they placed hand washing facilities with running water provided before workplace, as well as providing hygiene sanitation tools such as hand sanitizers at each entrance area and around the building area and more routinely cleaning the air circulation in the workspace. This is in line with statement that there are several things regarding the condition of the physical environment of the employee's workplace during Covid 19, namely air circulation, the size of the workspace, and work equipment (Hustia, 2020). The better the work environment such as good relations between leaders and subordinates as well as good relations between fellow subordinates and workplace conditions will be able to improve employee performance. The work environment in a company is important to note. The work environment can be seen from the physical (sufficient lighting, good air temperature, noise, wall paint, sufficient space for movement, security). A good work environment can support the implementation of work so that employees become more enthusiastic at work and can improve employee performance. The better the work environment such as good relations between leaders and subordinates as well as good relations between fellow subordinates and workplace conditions will be able to improve employee performance (Josephine \& Harjanti, 2017; Kusumastuti et al., 2019; Lestary \& Harmon, 2018).

\section{The work environment has a positive effect on employee performance through organizational commitment.}

The direct effect of the work environment on employee performance is 0.452 while the indirect effect of the work environment on employee performance through organizational commitment is 0.166 . With the multiplication result, it is obtained that the value is $0.452>0.166$. Which means that organizational commitment does not mediate the effect of the work environment on employee performance. The results of this study are in line with research which suggests that organizational commitment does not mediate the effect of the work environment on employee performance (Shanty \& Mayangsari, 2017). A facilitated work environment will increase employee performance such as workspace lighting which according to employees is adequate and good air circulation in the workspace. However, to improve performance, employees do not need to be previously committed to the company so that the creation of a pleasant work environment will directly affect employee performance. This is supported by the variable organizational commitment included in the medium category, this is because most of the respondents answered that the organizational commitment indicator is included in the medium category such as employees still working at the company because there is an emotional bond, employees are always involved in the organization, employees will continue to work in this company. because self-awareness and employees will continue to stay in this company because of obligations.

A good work environment can support the implementation of work so that employees become more enthusiastic at work and can improve employee performance. The better the work environment such as good relations between leaders and subordinates as well as good relations between fellow subordinates and workplace conditions will be able to increase organizational commitment to employees. This is supported by research which found a positive influence of the work environment on organizational commitment (Abidin et al., 2017; Putra et al., 2020; Wowor, 2016). In addition, the higher the work commitment felt by employees, the greater the employee's expectations that if they work to meet organizational goals. Good organizational commitment will be able to improve employee performance to achieve organizational goals. This is supported by the research which found a positive influence of organizational commitment on employee performance (A. Akbar et al., 2017; Charli et al., 2020; Lessar et al., 2019). The same thing was also found that the work environment had an effect on employee performance which was mediated by organizational commitment.

In order to improve employee performance, several things are needed, especially in work motivation, especially on the indicator with the lowest mean value, namely employees will work well if employees get attention from superiors and co-workers, therefore, for company leaders to give more attention or support to employees by how to give rewards for employees and for co-workers to help each other at work. In addition, from the work environment, especially the indicator with the lowest mean value, namely the work space is protected from noise, therefore for the company to add silencers in the workplace to reduce noise levels. The limitation of this research is the employee performance appraisal which is filled 
in by the employees themselves, this causes the responses given by the respondents to be subjective and have not examined the measurement of employee performance from the company. Therefore, for future research to add employee performance measurements from the company. This study only examines factors of work motivation and work environment as well as organizational commitment, therefore for future research to add other variables that can affect employee performance such as leadership.

\section{CONCLUSION}

Work motivation has an effect on employee performance. This means that the more motivated employees can improve employee performance. Organizational commitment does not mediate the effect of work motivation on employee performance. Good work motivation will increase employee performance. However, to improve performance, employees do not need to be committed to the company so that the good work motivation provided by the company will directly improve employee performance. The work environment affects employee performance. This means that the better the work environment can improve employee performance. Organizational commitment does not mediate the effect of the work environment on employee performance. A facilitated work environment will increase employee performance. However, to improve performance, employees do not need to be committed to the company beforehand so that the creation of a pleasant work environment will directly affect employee performance.

\section{REFERENCES}

Abidin, M. I. Z., Pongtuluran, Y., \& Maria, S. (2017). Pengaruh kepuasan kerja, lingkungan kerja dan efikasi diri terhdapa komitmen organisasi di rumah sakit smc samarinda. AKUNTABEL, 13(1), 1-10.

Akbar, A., Musadieq, M., \& Mukzam, M. (2017). Pengaruh Komitmen Organisasional Terhadap Kinerja (Studi pada Karyawan PT PELINDO Surabaya). Jurnal Administrasi Bisnis S1 Universitas Brawijaya, 47(2), 33-38. http://administrasibisnis.studentjournal.ub.ac.id/index.php/jab/article/view/1840.

Akbar, D. M., Tjahjono, H. K., \& Wahyuningsih, R. S. H. (2017). Pengaruh Motivasi Kerja Dan Kepuasan Kerja. Proceeding Health Architecture, 53-66. http://mmr.umy.ac.id/artikel/proceeding/\%0APENGARUH.

Amalia, S., \& Fakhri, M. (2016). Pengaruh Motivasi Kerja Terhadap Kinerja Karyawan Pada PT. Gramedia Asri Media Cabang Emerald Bintaro. Jurnal Computech \& Bisnis, 10(2), 119-127. https://jurnal.stmik-mi.ac.id/index.php/jcb/article/view/152.

Antonio. (2016). Remunerasi, Kompensasi dan Benefit. Rana Pustaka.

Azizah, N., Murgiyanto, M., \& Nugroho, R. (2019). Pengaruh Kepemimpinan Transformasional, Motivasi Kerja Terhadap Komitmen Organisasional Dan Kinerja Guru Pada SMK Abdurrahman Wahid Lamongan. Equilibrium: Jurnal Ekonomi-Manajemen-Akuntansi, 15(2), 240. https://doi.org/10.30742/equilibrium.v15i2.683.

Bintoro, D. S., Hartati, C. S., \& Winarko, R. (2019). Pengaruh Penilaian Kinerja dan Motivasi terhadap Komitmen Organisasional melalui Kepuasan Kerja Pada Kantor BEA Cukai Pasuruan. Jurnal Manajerial Bisnis, 2(3), 1-15. http://jurnal.uwp.ac.id/pps/index.php/mm/article/view/177.

Charli, C. O., Sari, P. I. P., \& Ade, F. S. (2020). Pengaruh Lingkungan Kerja, Motivasi Dan Kepuasan Kerja Terhadap Kinerja Karyawan Pada Perusahaan Daerah Air Minum (PDAM). Jurnal Pelita Indonesia, $3(1)$, $1-10$. http://www.ejournal.pelitaindonesia.ac.id/ojs32/index.php/PROCURATIO/article/view/595.

Dewi, R., \& Amilin. (2015). Pengaruh Komitmen Organisasi Terhadap Kepuasan Kerja Dengan Role Stress Sebagai Variabel Moderating. Jurnal Akuntansi Dan Auditing Indonesia, 12(1), 13-24. https://journal.uii.ac.id/JAAI/article/view/38.

Govender, M., \& Bussin, M. H. (2020). Performance management and employee engagement: A South African perspective. SA Journal of Human Resource Management, 18(1), 1-19. https: //doi.org/10.4102/sajhrm.v18i0.1215.

Hasibuan, M. (2012). Manajemen SDM. Bumi Aksara.

Hustia, A. (2020). Pengaruh Motivasi Kerja, Lingkungan Kerja Dan Disiplin Kerja Terhadap Kinerja Karyawan Pada Perusahaan WFO Masa Pandemi. Jurnal Ilmu Manajemen, 10(1), 81. https://doi.org/10.32502/jimn.v10i1.2929.

Josephine, A., \& Harjanti, D. (2017). Pengaruh Lingkungan Kerja Terhadap Kinerja Karyawan Pada Bagian Produksi Melalui Motivasi Kerja Sebagai Variabel Intervening Pada PT. Trio Corporate Plastic (Tricopla). AGORA, 5(3). http://publication.petra.ac.id/index.php/manajemenbisnis/article/view/6073. 
Kusumastuti, I., Ita Kurniawati, N., Loka Satria, D., \& Wicaksono, D. (2019). Analisis Pengaruh Lingkungan Kerja Terhadap Kinerja Karyawan Dimediasi Oleh Kepuasan Kerja Karyawan Pada Sp Alumunium Di Yogyakarta. Jurnal Riset Ekonomi Manajemen (REKOMEN), 3(1), 43-53. https://doi.org/10.31002/rn.v3i1.1540.

Lessar, J. Y., Serang, S., \& Sudirman, R. (2019). Pengaruh Lingkungan Kerja, Komitmen dan Disiplin Terhadap Kinerja Karyawan PT. Bank Rakyat Indonesia (Persero) Tbk Audit Interent Wilayah Makassar Interent Wilayah Makassar. Paradoks: Jurnal Ilmu Ekonomi, 2(3), 96-106. https://www.jurnal.fe.umi.ac.id/index.php/PARADOKS/article/download/255/172.

Lestari, I. D. (2016). Kepuasan Kerja Dan Motivasi Terhadap Komitmen. Sosio-E-Kons, 8(1), 15-24. https://journal.lppmunindra.ac.id/index.php/sosio_ekons/article/view/766.

Lestary, L., \& Harmon, H. (2018). Pengaruh Lingkungan Kerja Terhadap Kinerja Karyawan. Jurnal Riset Bisnis Dan Investasi, 3(2), 94. https://doi.org/10.35697/jrbi.v3i2.937.

Liang, J., Roberts, J., Ying, Z. J., Cao, J., Qi, M., \& Sun, M. (2015). Does working from home work ? Evidence from a chinese experiment. The Quarterly Journal of Economics, 130(1), 165-218. https://doi.org/10.1093/qje/qju032.Advance.

Luthans, F. (2006). Perilaku Organisasi. PT. Andi.

Mangkunegara, P. (2009). Evaluasi Kinerja Sumber Daya Manusia. Penerbit Refika Aditama.

Muhamad, R., \& Trang, I. (2019). Pengaruh Motivasi Intrinsik Dan Kompensasi Terhadap Komitmen Organisasi Dan Kinerja Karyawan (Studi Pada Karyawan PT. Konka Solusindo Manado). Jurnal EMBA: Jurnal Riset Ekonomi, Manajemen, Bisnis Dan Akuntansi, 7(1), 731-740. https://doi.org/10.35794/emba.v7i1.22529.

Neher, A., \& Maley, J. (2020). Improving the effectiveness of the employee performance management process: A managerial values approach. International Journal of Productivity and Performance, 69(6), 1129-1152. https://doi.org/10.1108/IJPPM-04-2019-0201.

Noah, Y., \& Steve, M. (2012). Work Environment and Job Attitude among Employees in A Nigerian Work $\begin{array}{lllll}\text { Organization. Journal of Sustainable } & \text { Society, } & \text { 1(2), }\end{array}$ http://worldscholars.org/index.php/jss/article/view/98.

Oktavianti, N. (2020). Pengaruh Motivasi dan Kepuasan Kerja terhadap Kinerja Kerja Karyawan PT. DEW Indonesia. JENIUS (Jurnal Ilmiah Manajemen Sumber Daya Manusia), 3(2), 148. https: //doi.org/10.32493/jjsdm.v3i2.3900.

Purnama., I., Nyoto., \& Komara, A. H. (2019). The Influence of Leadership Style, Work Motivation, Andwork Environment on Job Satisfaction and Employee Organizational Commitment in Pelita Indonesia Pekanbaru College. Procuratio: Jurnal Ilmiah Manajemen, 7(2), 152-164. http://www.ejournal.pelitaindonesia.ac.id/ojs32/index.php/PROCURATIO/article/view/443.

Purnama, N. Q., Sunuharyo, B. S., \& Prasetya, A. (2016). Pengaruh Motivasi Kerja terhadap Komitmen Organisasianal dan Kinerja karyawan (Studi pada Karyawan bank BRI cabang Kawi Malang). Jurnal Administrasi Bisnis (JAB), 40(2), 39-47.

Putra, P. D., Abdurrahman, D., \& Frendika, R. (2020). Pengaruh Lingkungan Kerja dan Organisasi Pembelajar Terhadap Komitmen Organisasi di Bank BJB Kantor Cabang Pembantu Cicadas Bandung. Prosiding Manajemen. http://karyailmiah.unisba.ac.id/index.php/manajemen/article/view/24299.

Rahsel, Y. (2016). Pengaruh Motivasi Kerja Terhadap Kinerja Pegawai Administrasi Pusat Universitas Padjadjaran Bandung (Studi Pada Bagian Administrasi Umum UNPAD). Jurnal Manajemen Magister, 2(1), 213. https://jurnal.darmajaya.ac.id/index.php/jmmd/article/view/902/596.

Sari, F., Sudiarditha, I. K. R., \& Susita, D. (2021). Organizational Culture and Leadership Style on Employee Performance: Its Effect through Job Satisfaction. The International Journal of Social Sciences World (TIJOSSW), 3(2),

https://growingscholar.org/journal/index.php/TIJOSSW/article/view/140.

Setiawan, R., \& Lestari, E. P. (2016). Pengaruh budaya organisasi, komunikasi, lingkungan kerja dan motivasi terhadap komitmen organisasi dalam meningkatkan kinerja pegawai. Jurnal Organisasi Dan Manajemen, 12(2), 169-184. https://sktutor.fkip.ut.ac.id/index.php/jom/article/view/60.

Shanty, D., \& Mayangsari, S. (2017). Analisis Pengaruh Kompensasi, Motivasi, Lingkungan Kerja Terhadap Kinerja Karyawan Dengan Komitmen Organisasional Sebagai Variabel Intervening. Jurnal Informasi Perpajakan Akuntansi Dan Keuangan Publik, 12(2), 103-120. https://www.trijurnal.lemlit.trisakti.ac.id/jipak/article/view/5114.

Siahaan, S., \& Bahri, S. (2019). Pengaruh Penempatan, Motivasi, Dan Lingkungan Kerja Terhadap Kinerja Pegawai. Maneggio: Jurnal Ilmiah Magister Manajemen, 2(1), 16-30. https://doi.org/10.30596/maneggio.v2i1.3402.

Sugiyono. (2012). Metode Penelitian Kuantitatif Kualitatif dan R\&B. Alfabeta. 
Syardiansah, S., Mora, Z., \& Safriani, S. (2020). Pengaruh Kepuasan Kerja, Budaya Organisasi dan Komitmen Organisasi Terhadap Kinerja Karyawan. Jupiis: Jurnal Pendidikan Ilmu-Ilmu Sosial, 12(2), 438. https://doi.org/10.24114/jupiis.v12i2.16771.

Syawal, M. A. (2018). Pengaruh Motivasi, Kepuasan Kerja, dan Komitmen Organisasional Terhadap Kinerja Karyawan pada Cv. Mega Jasa. Jurnal Administrasi Bisnis Ekonomi, 1(1), 1-5. http://ejournals.unmul.ac.id/index.php/TI/article/view/1167.

Taiwo, A. S. (2010). The influence of work environment on workers productivity: A case of selected oil and gas industry in Lagos, Nigeria. African Journal of Business Management, 4(3), 299-307. https://academicjournals.org/journal/AJBM/article-abstract/969A43121535.

Veithzal, R. (2005). Manajemen Sumber Daya Manusia Untuk Perusahaan Dari teori Ke Praktik. PT. Raja Grafindo Persada.

Wasiati, H. (2016). Kepimimpinan, Lingkungan Kerja terhadap Kinerja Pegawai dengan Kepuasan Kerja sebagai Variabel Intervening. Jurnal Bisnis Dan Ekonomi, 14(2), 190-200.

Wowor, G. (2016). Pengaruh Lingkungan Kerja Dan Disiplin Terhadap Komitmen Organisasional Pada Karyawan Media Cahaya Pagi. Jurnal Administrasi Publik, 3(38). 